\title{
An entrepreneurial stance towards education of information professionals ${ }^{1}$
}

\author{
Elizabeth D. Liddy \\ Syracuse University, Syracuse, NY, USA \\ E-mail: liddy@syr.edu
}

\section{Context}

Two points I'd like to make up front. First, while I dislike being contrary, I do not think it possible to think forward in any reliable way as to what education for an Information Professional in 2050 will be. How can we do this when in 2007 we could hardly have predicted 2012! Second, my thoughts are going to be highly reflective of the personal experiences I've had and learned from - both preceding my time as a dean and the broader perspective I've gained in the last 4 years as Dean of just one of the 36 international iSchools. Although my role as the Chair of the iSchool Caucus does impact and inform me - I will reflect much more based on my experiences as Dean of the iSchool at Syracuse - which may or may not be typical of the broader information education arena.

So if I can't do what I was assigned in this position paper - what can I do? If we can't plan for a future that is 38 years away, what can we do? My answer is that the best thing we can do is to take an entrepreneurial stance. To those who know me, this will not come as a surprise - in fact I describe myself in my Twitter profile, @lizliddy, as "Entrepreneurial Academic". So the question is, how do we do that, or if in fact have we actually done that, and if so, how?

First we need simply to adopt an entrepreneurial mind-set. That is - be alert, stay attentive, receptive, willing to risk, able to recognize and sustain competitive advantage and most of all - be agile. We need to be open to all disciplines, methods, programs, partnerships, problems and new ways of leading our schools. The biggest risk to our schools, our faculty, and our students of not being as successful as there is potential to be, would be if we are not open to new ways of thinking and acting.

\section{Challenges}

As I stated above, I prefer to talk about that which I know well and which I have seen work successfully. And I truly believe, based on everything I've seen, read or experienced, that an entrepreneurial

\footnotetext{
${ }^{1}$ This work is licensed under the Creative Commons Attribution-Noncommercial No Derivations Works 3.0 Unported license. You are free to Share this work (copy, Distribute and transmit) under the following conditions: attribution, noncommercial and no derivative works. To view a copy of this license, visit http://creativecommons.org/licenses/by-nc-sa/3.0/.
} 
stance is exactly what the academic information field must take. But the issue is how to do that within an academic environment. I know it is challenging within what can be very bureaucratic, slow-moving universities, but I think that an increasing number of them are becoming more agile and open to more empowering models. The most important of these is the financial model, and those fortunate enough to be in a university with Responsibility Centered Management (RCM), which couples school-level decision making directly with financial responsibility, vs. the older model where a Dean has authority but not control of their own budget and financial decisions, can attest to the increased ability to be entrepreneurial in a RCM-based university.

Additionally, while planning and implementation of new initiatives in the academic world has been traditionally slow, this must be overcome if universities are to be optimally successful in today's quick changing environment, and I do see this increasingly as a trend, but frequently academia is not sufficiently quick-moving to support the most entrepreneurial of ideas. Fortunately, private universities are better able to take advantage of new opportunities because they do not have the extra layers of bureaucracy and needed approvals that exist for state universities.

But even if a University is supportive of entrepreneurial initiatives, we must also have both faculty and administrators within our individual schools who are empowered by their Dean, and an environment that the Dean creates which is ready, willing and able to react quickly to the opportunities that abound in a world environment which is increasingly information dependent. Furthermore, the fact that information schools typically have very talented IT staff provides an advantage in that our schools are able to quickly adopt new technologies as they are introduced, or invent them ourselves to provide new modes and methods of instruction and research. We can more easily flip classes, provide innovation studios, create sandboxes for student start-ups and stay on the leading edge of collaboration toolkits and online learning technologies.

\section{Recommendations for courses, activities and experiences}

So given an entrepreneurial stance, what courses, programs and experiences are/can the iSchools offer to ensure that our students will succeed in the ever-evolving professional world they will face for all of their unforeseeable future?

What I feel I can say is that we don't know now all of what these will be - but I can predict that they will be ever-new and changing. I know this from very recent experience - our 3 fastest growing curricular areas of focus, research and attraction were not in existence just a few years ago - namely Social Media, Information Entrepreneurship and Data Science. While these 3 are going strong, we also know that there will be even newer ones every year. To enable us to make new domains of offerings available quickly, we get them started as very 'light-weight' options that do not require multiple levels of review and approval, but can be quickly mounted as specializations within our degree programs. Waiting for the arduous, formal process would mean that we would not be the innovative school that we aim to be. In the traditional many-staged process which schools have followed, there are typically at least six steps:

Traditional academic offering approval process:

Faculty Member Proposal $\rightarrow$ Department $\rightarrow$ School $\rightarrow$ Senate $\rightarrow$ Trustees $\rightarrow$ State $\rightarrow$ APPROVAL 
However, by choosing 'light-weight' options, such as specializations and Certificates of Advanced Study (CAS), we have successfully shortened this process to two steps:

Agile academic offering approval process:

$$
\text { Faculty Member Proposal } \rightarrow \text { School } \rightarrow \text { APPROVAL }
$$

In addition, to enable us to quickly mount new CASs at the graduate level, we proposed and got university and state approval for a CAS in Information Innovation: That colon is key, as we can particularize it by adding an extension without the need to go back for approval when we do so.

\subsection{Social media}

As a first example - a few years ago, one of our school's IT staff who had been teaching for us as an adjunct, asked if he could offer a course in Social Media, and, being a SM fan, I immediately said yes. Only 5 students enrolled that first semester, but I said we would go with it anyways. Slowly, the tweets and posts from this course attracted a lot of followers amongst our own students, plus students from communications, management and design who started dropping in until the room was full for each class. We now have multiple highly-rated and well-subscribed Social Media courses. Social Media is now both an undergrad specialization and a graduate CAS in Information Innovation: Social Media.

And that IT person was hired onto our faculty as a Professor of Practice, and was subsequently invited to brief both NASA and the US Senate on appropriate use of Social Media for their particular environments. Such Professors of Practice (full-time, non-tenure-track faculty), of which we now have 17, offer another means for staying agile, that I believe will trend, as Professors of Practice are on 3 year contracts, and while many of our Professors of Practice have been with us for quite a while, we can always choose to not renew their contracts if and when their area of practice and expertise is no longer in demand by our students - all of whom are professional students seeking to learn the latest technologies and skills that will enable them to get the jobs that are so well paying, or advance in the jobs they are already in, who highly value the real world expertise that Professors of Practice bring to the classroom. Quite different from some tenured faculty, for whom curriculum is frequently faculty autobiography.

\subsection{Entrepreneurship minor}

Once we take an entrepreneurial stance as the optimal strategy for the iSchools, I believe it essential for our schools to be actively creating enterprises themselves - for, with, and by our students, as well as our faculty. While this is encouraged and supported at a number of universities, as Thorp \& Goldstein point out in their book Engines of Innovation [1], these programs at MIT, Stanford, etc., have typically been located in engineering or management schools, with other disciplines recently joining in. I strongly recommend that the iSchools exercise their acknowledged centrality to optimal business success today, and become the natural locus of academic entrepreneurship specializations.

As an example of the entrepreneurship education opportunities that we have been very actively pursuing since 2009, we offer an inter-disciplinary, 18-credit minor in 'Information Technology, Design \& Start-Ups' - referred to as IDS, which prepares students with the knowledge and skills required to start and run their own information technology-oriented ventures. It is an inter-disciplinary minor led by the iSchool, along with the School of Management, and the Design Program in the College of Visual \& 
Table 1

Growth of Student StartUp SandBox since creation

\begin{tabular}{lcccc}
\hline & 2009 & 2010 & 2011 & 2012 \\
\hline Applicant student company teams & 5 & 18 & 39 & 129 \\
SandBox companies/teams & 5 & 12 & 32 & 45 \\
Mentors & 4 & 40 & 70 & $100+$ \\
Start-Up Competition winnings & $36 \mathrm{~K}$ & $90 \mathrm{~K}$ & $135 \mathrm{~K}$ & $150 \mathrm{~K}$ \\
\hline
\end{tabular}

Performing Arts. The minor consists of 4 entrepreneurship courses (along with electives), culminating in a full-time summer course in the Student Sandbox. These are:

- What's the big idea? Technology innovation (3 credits).

- Entrepreneurship fundamentals (3 credits).

- Idea2Startup: technology entrepreneurship (3 credits).

- StartUp Sandbox (1-6 credits).

In the Student StartUp Sandbox experience, a full time Entrepreneur-in-Residence coaches the student teams through their venture-creation and serves as a conduit to the community. Each team has up to 5 assigned community mentors who are entrepreneurs, technologists, subject matter experts, attorneys, and accountants. At the Ray von Dran IDEA awards at Emerging Talk, student teams from SU and 4 other upstate New York colleges compete for seed-funding for full time summer support in the Sandbox, and other student ventures can and do self-support themselves. Table 1 displays some of the vital growth aspects of the SandBox. Several of our Student Sandbox ventures have received substantial angel or venture funding. To date, receiving close to $\$ 3 \mathrm{M}$ in investment funding.

\subsection{Faculty entrepreneurship}

In addition to supporting student entrepreneurship, I believe that our information schools need to be equally encouraging of faculty entrepreneurship. There are obvious trends in universities being more supportive, and again I believe that the faculty we have in information schools make us ideally situated to reap the amazing benefits when faculty do start-ups simultaneously while carrying out their responsibilities as faculty. I know this first-hand, because I myself formed and led an early internet search engine company (which I exited successfully after 5 years of growing the company, which is still in existence) all the while being a faculty member in the iSchool at Syracuse, and housing the technical side of the company (50 people) within the iSchool, all while teaching and supporting numerous students.

Another such example is our Associate Professor of Practice, Jeff Rubin, who was a product of both our undergrad and graduate programs, and who as a Masters student started his own company (Internet Consulting Services), while also teaching as an adjunct. As Jeff tells it, the faculty were his mentors then - and now as a faculty member, he is a mentor for many student start-ups. His company (which now has a division called SideArm Sports), has 572 college athletic departments as its customers, to whom he has licensed his website software \& who continuously buy ongoing service. ICS is or has done work for the World Bank, SONY Music, the Discovery Channel and the New York State Department of Health, among others.

Jeff's company is situated within the iSchool where he pays rent for the space he occupies, employs 21 full-time employees, as well as 25 part-time student employees. In parallel, he teaches courses of $200+$ UGs from across campus, and is a very supportive donor to our Ray von Dran IDEA Student Start-Up Program. Jeff recently did an interview which I participated in, during which he shared some 
thoughts which I believe encourage us all to seriously invest in support of our faculty entrepreneurs. For example, Jeff said "There is no way I would be where I am now without the relationship with the university". As well as "You can't put a value on what it means to be part of the university - while it's a win-win, you can't say who wins more than the other". And thankfully for me, since Jeff is one of our most highly-rated professors, he said "I could never imagine a day when I would stop teaching".

So, not only do faculty entrepreneurs contribute tremendously in their own right - in terms of the prestige and reputation they bring to the school, but they contribute to the excitement and eagerness that our students pick up on regarding the 'real life' aspect of the information field, which they learn from faculty entrepreneurs who openly discuss their experiences in classes.

I share these individualized stories because I believe they are good exemplars of what we and all the schools in our field can do, and which I personally think we must do - both for the health of our schools, as well as the most appropriate preparation of our professional students.

\section{Conclusion}

So where will an entrepreneurial stance towards education for Information Professionals take us in the years ahead? As I've said, I base my comments on what I've learned from what we've done in the iSchool at Syracuse University. In summary, what we have experienced by being entrepreneurial is tremendous growth in student body, faculty and staff; financial success; strong reputation; and an appropriately wider diversity in academic programs given the centrality of information to so many professions.

A little history illustrates this - our school was founded at Syracuse University in 1896 as a Library School, and then in 1974, it was the first to become an Information School. In subsequent years, we have added a PhD program, a BS in Information Management \& Technology, two dual undergraduate degrees, two more Masters degrees (Information Management; Telecommunications \& Network Management), an Executive Masters, a Professional Doctorate and 9 Certificates of Advance Study.

In addition, as we look to our future of library and information science education, how and where we teach has changed and will continue to change. For example, we began offering online programs 17 years ago, and today approximately one third of our masters degrees are earned fully online, and of our main campus students, approximately $65 \%$ of them took at least one online course in the last 2 years.

So, up until 1969, 100\% of our 113 students were Masters of Library Science students, while today, although the absolute number of MLIS students has grown, they comprise only $13 \%$ of our total student population of 1394 students. And looking at just the Masters level programs, only 35\% of the masters students are MLIS. I believe this suggests something for the breadth of where the future lies for Information Professionals, amongst whom you will find high-performing information graduates of all types, including many from our new Entrepreneurial Librarianship Program.

\section{Reference}

[1] H. Thorp and B. Goldstein, Engines of Innovation: The Entrepreneurial University in the Twenty-First Century, University of North Carolina Press, Chapel Hill, NC, 2010. 